\title{
Carbon Dioxide Flux at the Water-Air Boundary at the Continental Slope in the Kara Sea
}

\author{
A. A. Polukhin ${ }^{a, *}$, M. V. Flint ${ }^{a}$, I. B. Belikov ${ }^{b}$, G. V. Gusak ${ }^{c}$, U. A. Kazakova ${ }^{d}$, V. O. Muravya ${ }^{a}$, \\ N. V. Pankratova ${ }^{b}$, Yu. O. Pronina ${ }^{a}$, A. I. Skorokhod ${ }^{b}$, A. L. Chultsova ${ }^{a}$, and A. S. Shchuka ${ }^{a}$ \\ ${ }^{a}$ Shirshov Institute of Oceanology, Russian Academy of Sciences, Moscow, Russia \\ ${ }^{b}$ Obukhov Institute of Atmospheric Physics, Russian Academy of Sciences, Moscow, Russia \\ ${ }^{c}$ St. Petersburg State University, St. Petersburg, Russia \\ ${ }^{d}$ Moscow State University, Moscow, Russia \\ *e-mail:polukhin@ocean.ru
}

Received May 28, 2021; revised May 31, 2021; accepted June 4, 2021

\begin{abstract}
The values and direction of carbon dioxide flux in the area of the continental slope in the north of the Kara Sea (St. Anna Trough) are calculated based on field studies in 2020 within the Siberian Arctic Sea Ecosystems program. The existence of a stable frontal zone in this area has been confirmed, which is formed by an alongslope current and limits the northward spread of surface waters freshened by the continental runoff. The simultaneous analysis of the carbonate system in the upper sea layer and the $\mathrm{CO}_{2}$ concentration in the surface air layer shows the $\mathrm{CO}_{2}$ flux with a rate of 0.2 to $22 \mathrm{mmol} / \mathrm{m}^{2}$ day to be directed from the atmosphere into the water in the area of the outer shelf, which is affected by the river runoff, and in the area of the continental slope, which is beyond this effect. The highest rates of $\mathrm{CO}_{2}$ absorption by the sea surface layer are localized above the continental slope. Local processes in the area of the slope frontal zone determine the $\mathrm{CO}_{2}$ emission into the atmosphere with a rate of $0.34 \mathrm{mmol} / \mathrm{m}^{2}$ day.
\end{abstract}

Keywords: Arctic, Kara Sea, continental slope, ecosystem, carbon dioxide balance

DOI: $10.1134 /$ S0001437021050118

\section{INTRODUCTION}

The $\mathrm{CO}_{2}$ effect on Earth's climate and on the living conditions of marine organisms causes high interest in the study of the carbonate system of ocean waters, which becomes of particular importance in connection with the increasing anthropogenic emissions of $\mathrm{CO}_{2}$ into the atmosphere. Recent data corroborates the beginning of a change in the carbonate equilibrium of the World Ocean water due to the increase in the atmospheric $\mathrm{CO}_{2}$ content [17]. Most researchers believe that an increase in atmospheric $\mathrm{CO}_{2}$ in the upper ocean layer can result, and already results in some regions, in changes in the chemical composition of waters and their acidification, which will be unfavorable or even fatal for some marine animal species. On the other hand, the ocean can play a significant role in the $\mathrm{CO}_{2}$ cycle, absorbing it from the atmosphere and reducing the impact of its anthropogenic emissions.

To forecast the global response of the atmosphere and hydrosphere to an increase in the $\mathrm{CO}_{2}$ content in air, the question of the direction and intensity of the exchange of $\mathrm{CO}_{2}$ between the ocean and the atmosphere is of great importance. $\mathrm{CO}_{2}$ fluxes in the atmo- sphere-ocean system can differ in the same ocean areas depending on the season, time of day, and hydrophysical and biological processes [22]. The general prevalence of carbon dioxide absorption by the ocean over its emission is now considered proven [12]. However, there are large discrepancies in the assessments of $\mathrm{CO}_{2}$ fluxes and contributions of individual oceans and large oceanic regions into the global balance of $\mathrm{CO}_{2}$ exchange.

The current climate changes are most pronounced in the Arctic, and the greatest variability of the carbonate system of waters can be expected in the Arctic Ocean (AO) [10, 16, 21]. To understand the complex interaction between the main factors of water acidification in the Arctic Ocean and its marginal seas (growth of atmospheric $\mathrm{CO}_{2}$, freshening, and terrigenous runoff), it is necessary to understand the current state of the carbonate system of waters of the Arctic seas of Russia and their differences according to the natural conditions of the water areas.

Inorganic carbon compounds are found in the ocean in the form of carbonic acid and its derivatives, including carbon dioxide $\mathrm{CO}_{2}$, carbonic acid $\mathrm{H}_{2} \mathrm{CO}_{3}$, and hydrocarbonate $\mathrm{HCO}_{3}^{-}$and carbonate $\mathrm{CO}_{3}^{2-}$ ions. 


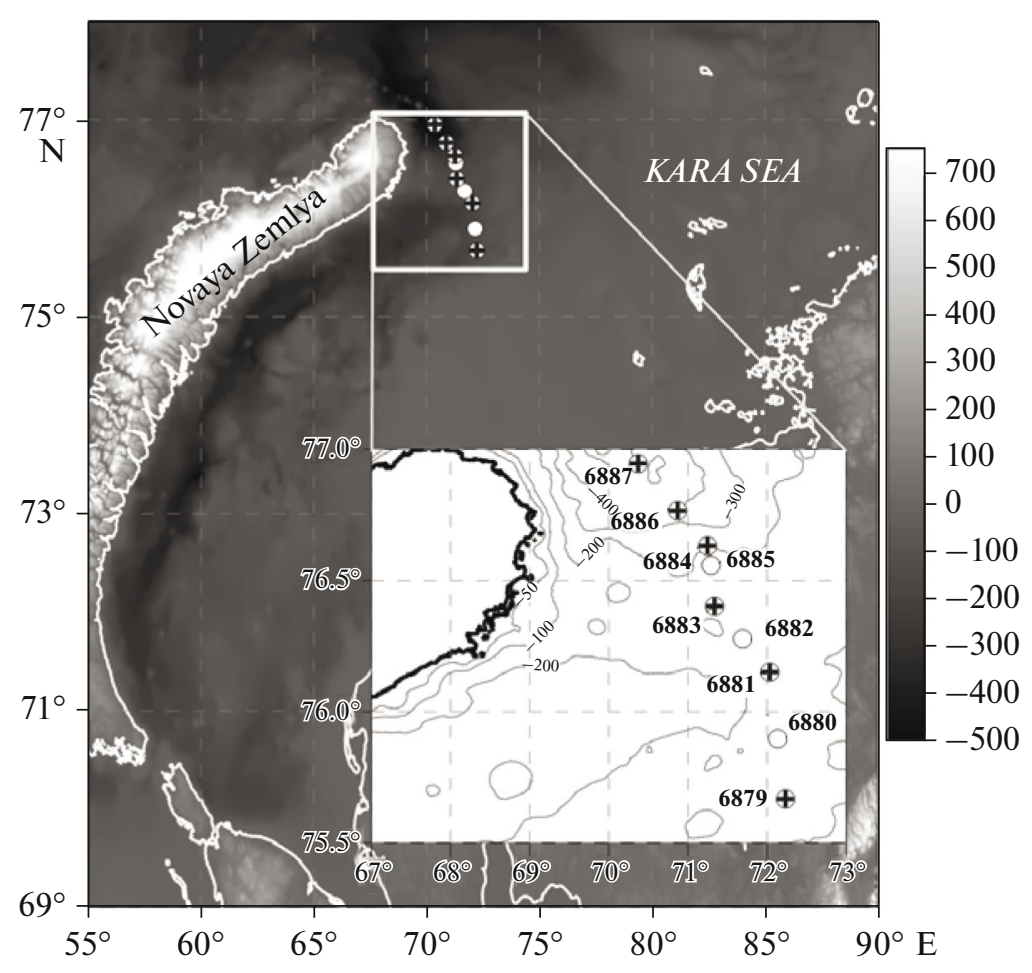

Fig. 1. Positions of hydrological stations (circles) and stations where hydrochemical sampling was performed (crosses) during the 81st cruise of Akademik Mstislav Keldysh near the continental slope in the Kara Sea.

These compounds are closely connected with each other and form the carbonate system [1]. The report of the Intergovernmental Panel on Climate Change (IPCC) released in September 2019 on the basis of 7000 scientific publications has shown possible consequences of increases in the air temperature and anthropogenic $\mathrm{CO}_{2}$ emissions into the atmosphere for polar regions and their population [15]. Changes in the $\mathrm{CO}_{2}$ balance parameters in the atmosphere-ocean system are of fundamental importance for marine ecosystems, since their functioning, first of all, the phytoplankton composition and primary production of organic matter, is directly related to the content of different forms of carbon in water.

Model calculations [23] and analysis of field data [20] have shown high variability of the parameters of the carbonate system of the Kara Sea, a decrease in $\mathrm{pH}$ of its water, and its saturation with aragonite, which is an indicator of the acidification process. The dynamics of the runoff of the largest Siberian rivers, $\mathrm{Ob}$ and Yenisei, has been ascertained to be an important factor of this variability $[13,20]$. However, the direction and intensity of $\mathrm{CO}_{2}$ flux at the ocean-air boundary has been insufficiently studied for different regions of the Kara Basin. We believe this study to be important for understanding the cycle of inorganic carbon in the Arctic seas and its effect on the carbonate system of waters and sea-air fluxes.

\section{MATERIALS AND TECHNIQUES}

Data on the hydrophysical and hydrochemical water parameters were received during the 81st cruise of the Akademik Mstislav Keldysh research vessel (RV) in the Kara Sea within the Siberian Arctic Sea Ecosystems program. In the region of the outer shelf and the continental slope of the western trough of the St. Anna Trough, a quasi-meridional section of nine hydrological stations was performed (September 2-4, 2020); samples for hydrochemical analysis were sampled at six of them (Fig. 1). The temperature and salinity were measured with a SBE19 CTD profiler. The carbonate system parameters ( $\mathrm{pH}$ and total alkalinity, Ta) were determined in water samples with the Rosette complex at layers selected while accounting for the hydrological structure.

The $\mathrm{pH}$ values in the samples were potentiometric estimated with a HANNA 2210 device (USA), and Ta values, with a semi-automatic TitroLine easy titrator (Italy) with visual determination of the end point of titration by techniques adopted at the Shirshov Institute of Oceanology, Russian Academy of Sciences [6], in accordance with international practice [11]. The content of dissolved carbon dioxide and derivatives (carbonate and bicarbonate ions), $\mathrm{CO}_{2}$ partial pressure $\left(\mathrm{pCO}_{2}\right)$, and saturation with calcite and aragonite were calculated by the $\mathrm{pH}$-Alk technique by thermodynamic equations of carbonate equilibrium in the 

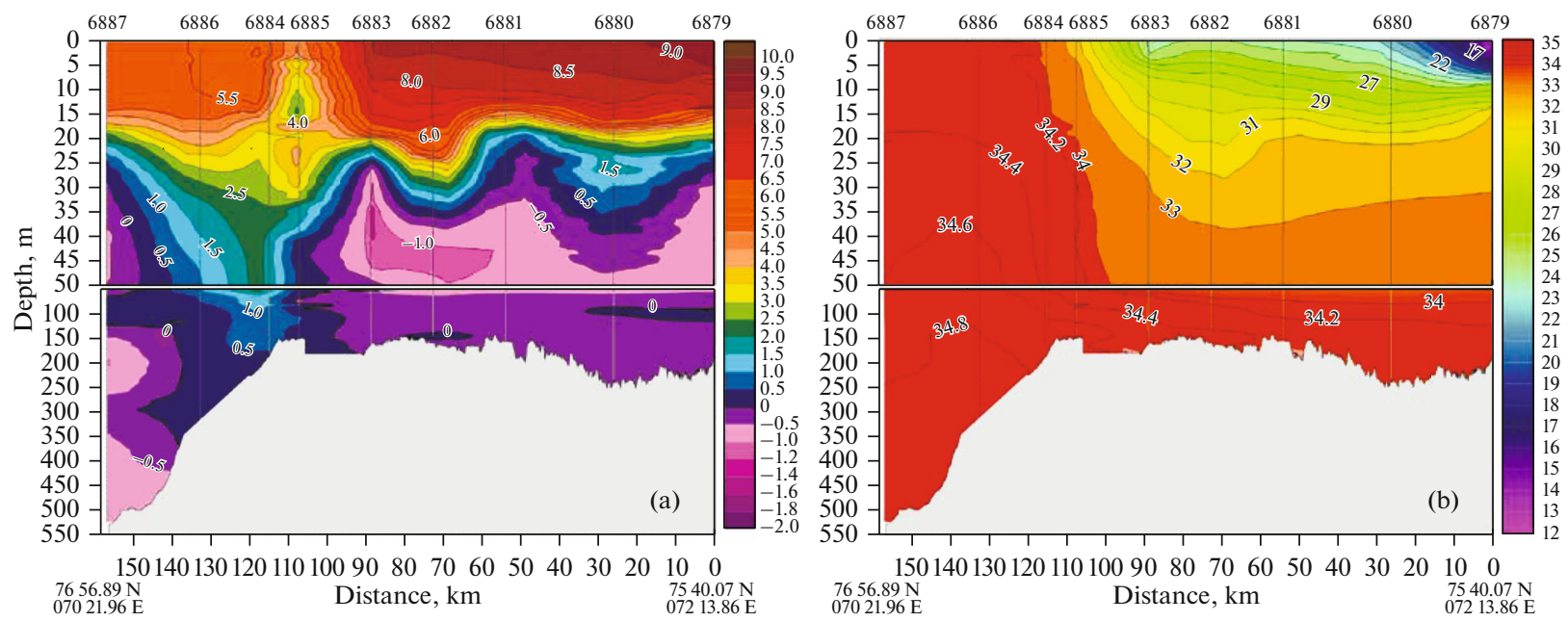

Fig. 2. Sectional distribution of the (a) temperature, ${ }^{\circ} \mathrm{C}$, and (b) salinity, PSU, in the St. Anna Trough in September 2020.

$\mathrm{CO} 2$ sys software [14]. Data on the $\mathrm{CO}_{2}$ content in the surface air layer were received using a Picarro G2132-i gas analyzer (USA); the measurement technique is described in [19]. The $\mathrm{CO}_{2}$ flux was calculated from the difference between $p \mathrm{CO}_{2}$ in water and air using the wind speed measured at the sampling point by the technique described in [24].

\section{RESULTS AND DISCUSSION}

The section performed covered the region of the outer shelf and continental slope with depths from 200 to $500 \mathrm{~m}$. A feature of this region is a high-power contour current jet strongly related to the slope topography, the core of which is formed by warm Atlantic and Barents Sea waters $[3,7]$. The presence of the current determined the formation of the frontal slope area, clearly pronounced in the temperature and salinity data [3, 7-9]. Our data once again confirmed these features of the water circulation and structure in the area of the continental slope of the St. Anna Trough. The current jet and the frontal slope zone were well identified in the temperature and salinity fields in the upper 50-100 $\mathrm{m}$ layer and were localized over the upper part of the continental slope (Fig. 2, station 6885).

The specific alkalinity index (the ratio of total alkalinity to salinity) is an indisputable marker of the presence of a river signal in the waters of the Kara Basin [5]. The isoline of the specific alkalinity index equal to 0.07 , which points to the river runoff influence in the $0-20 \mathrm{~m}$ layer, is traceable in the southern part of the section up to the northern periphery of the frontal slope zone (Fig. 3, station 6884).

The regression analysis with the alkalinity and salinity data in the upper layer of the section has shown dependence

$$
Y=40.922350 X+854.79
$$

where $Y$ is the alkalinity; $X$ is the salinity; and the free term characterizes the alkalinity at the starting point of mixing, i.e., in the river water.

The total alkalinity value equal to $854 \mu \mathrm{M}$ is characteristic of Yenisei river water in summer [5]. These numbers and the free term in the above equation allow us to conclude with a high probability that the freshening of the water area under study during the period of our research was the result of the impact of the Yenisei runoff. This is not a unique situation for the Kara Sea, Yenisei waters have been repeatedly observed far to the north of the source [5]. This fact is due to the highpower Yenisei water discharge during the spring flood and the contribution of the Yenisei waters to the formation of the surface fresh "lens" in the Kara Sea, which is transported by prevailing winds, including in the northern direction $[2,18]$.

The sectional distribution of $\mathrm{CO}_{2}$ partial pressure is connected with the regional hydrophysical structure (Figs. 2 and 3b). In the freshening surface layer on the outer shelf between stations 6879 and $6883, p \mathrm{CO}_{2}$ was above $400 \mathrm{ppm}$, which is typical for the Kara Sea affected by river runoff [20]. At the seaward stations of the section (stations 6884-6887), in the upper biologically active layer $0-60 \mathrm{~m}, p \mathrm{CO}_{2}$ was $252-353 \mathrm{ppm}$. Below $100 \mathrm{~m}$ and in the bottom layer, $p \mathrm{CO}_{2}$ significantly exceeded an equilibrium value of $400 \mathrm{ppm}$ and attained 500-600 ppm in all areas crossed by the section (Fig. 3b). These high values are associated with the oxidation of organic matter coming from the upper layer. The northern periphery of the frontal zone above the upper part of the continental slope (Fig. 3b, station 6884) was an exception; there, the absence of pronounced vertical stratification in the $p \mathrm{CO}_{2}$ distribution and deepening of the $400 \mathrm{ppm}$ isoline almost to the bottom $(180 \mathrm{~m})$ were noted. This character of $p \mathrm{CO}_{2}$ distribution confirms the specificity of local processes associated with the frontal slope zone. 

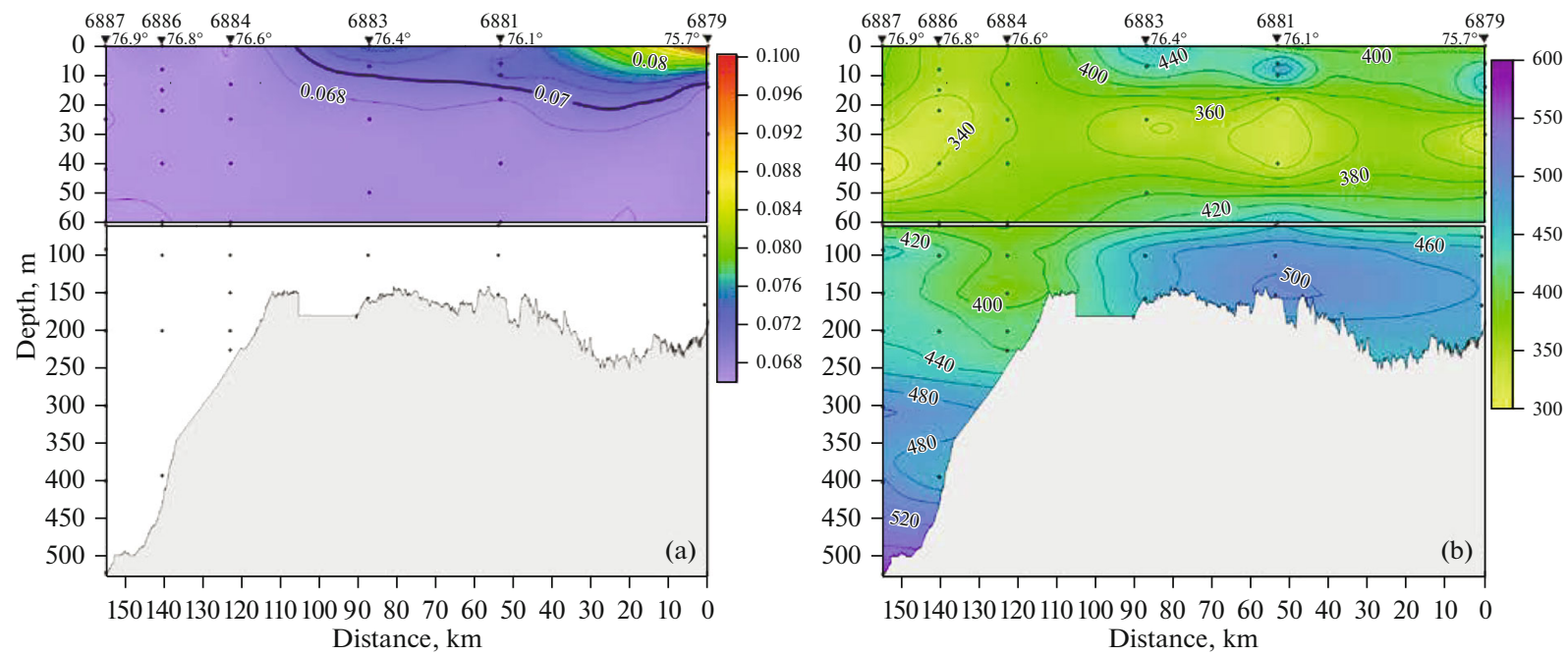

Fig. 3. Sectional distribution of the (a) specific alkalinity and (b) $\mathrm{CO}_{2}$ partial pressure, ppm in the St. Anna Trough in September 2020.


Fig. 4. $\mathrm{CO}_{2}$ concentration, ppm, in the surface air layer in the studied Kara Sea region in September 2020.

The seasonal minimum in the $\mathrm{CO}_{2}$ concentration is observed in the Arctic in late June-early August; thus, the measurement period over the Kara Sea almost coincided with the annual minimum. The $\mathrm{CO}_{2}$ concentration measured ranged from 389 to $430 \mathrm{ppm}$ with a mean of $396 \mathrm{ppm}$. High $\mathrm{CO}_{2}$ values were determined by polluted air carried from the mainland (long-term maxima) or from the ship's chimney (short-period, jumping values). Figure 4 shows the series of $\mathrm{CO}_{2}$ concentration with filtered out events of the ship's chimney effect ( $\sim 5 \%$ of the total number of measurements). The data received in July 2019 (the 76th cruise of the $\mathrm{RV}$ ) show the $p \mathrm{CO}_{2}$ minimum to be at least $380 \mathrm{ppm}$, which is explained by the seasonal variability of this parameter and the general increase in the $\mathrm{CO}_{2}$ content in the atmosphere. In addition, 2020 became a record hot year in the Arctic; the temperature exceeded the average over $1981-2010$ by $4.3^{\circ} \mathrm{C}$ in the Siberian part; an increase in the activity of wildfires in summer and, hence, an increase in the $\mathrm{CO}_{2}$ concentration in the atmosphere were noted.

The direction and rate of the $\mathrm{CO}_{2}$ flux at the water-air boundary were calculated for the area of the continental slope of the St. Anna Trough, where several specific hydrophysical, hydrochemical, and biological phenomena were observed, and for the area of the outer shelf (Fig. 5). These calculations showed the 
$\mathrm{CO}_{2}$ flux direction from air to water and its rate of 1 to $22 \mathrm{mmol} / \mathrm{m}^{2}$ day at five of six stations in the section. The highest rates of $\mathrm{CO}_{2}$ absorption by the sea surface layer were noted at the northern periphery of the frontal slope zone and above the continental slope (stations 6884,6886 , and 6887). That area was not affected by the continental runoff and, as a consequence, there was no rigid stratification, which limited the vertical mixing. Station 6883 stands out from the general patter; there, the $\mathrm{CO}_{2}$ flux $\left(0.34 \mathrm{mmol} / \mathrm{m}^{2}\right.$ day $)$ had the opposite direction, from water to air. That station was performed at the southern shelf periphery of the frontal slope zone, which limits the northward spread of waters freshened by river runoff (Figs. 2 and 3).

Figure 6 shows the joint spatial variability of $p \mathrm{CO}_{2}$ in the atmosphere and the upper sea layer at the section. The $p \mathrm{CO}_{2}$ value varied from 340 to $415 \mathrm{ppm}$ in the water area near the outer shelf, under the river freshening effect (stations 6879-6883), at a sea surface temperature of $9-9.5^{\circ} \mathrm{C}$. The maxima were noted at the southern periphery of the frontal slope zone (station 6883), which is marked out by a relatively sharp decrease in the temperature from 9 to $5-6^{\circ} \mathrm{C}$ $\left(0.18^{\circ} \mathrm{C} / \mathrm{km}\right)$ in the upper sea layer. At the same time, $p \mathrm{CO}_{2}$ in the surface air layer in this part of the section slightly varied, about $395 \mathrm{ppm}$. In the frontal zone (station 6884 and the water area immediately adjacent from the south, Fig. 2), $p \mathrm{CO}_{2}$ in the atmosphere increased to $433 \mathrm{ppm}$. To the north of the frontal zone in the area of the continental slope, at a relatively low surface water temperature, $p \mathrm{CO}_{2}$ in water and in air decreases to $312-347$ and $395 \mathrm{ppm}$, respectively.

Our results make it possible to estimate the $\mathrm{CO}_{2}$ exchange in the sea-air system in the region of the continental slope and their relationship with the hydrophysical and hydrochemical structure. The frontal zone above the continental slope of the St. Anna Trough is formed as a result of interaction of surface shelf waters with low (28-29 PSU) salinity, due to the continental runoff, with winter waters of the Kara Sea with negative temperatures, which lies beneath the pycnohalocline, and transformed Atlantic waters with a higher surface salinity than in the Kara Sea and a higher temperature in the core. The frontal slope zone of the St. Anna Trough is well marked out by the distribution of hydrochemical characteristics, for example, nitrate and ammonium nitrogen [4], chlorophyll, and phytoand zooplankton $[8,9]$. In our studies, it is detected by the $\mathrm{CO}_{2}$ partial pressure in the water depth and in the surface air layer. Low $p \mathrm{CO}_{2}$ values (relative to the equilibrium $400 \mathrm{ppm}$ ) in the upper sea layer above the continental slope (stations 6884, 6886, and 6887) are probably connected with the photosynthetic activity of phytoplankton, as indicated by high saturation of water with dissolved oxygen $(>100 \%$ in the $0-20 \mathrm{~m}$ layer). In this area, the $\mathrm{CO}_{2}$ flux is directed from air, where $p \mathrm{CO}_{2}$ varies within $395-430 \mathrm{ppm}$, to water,

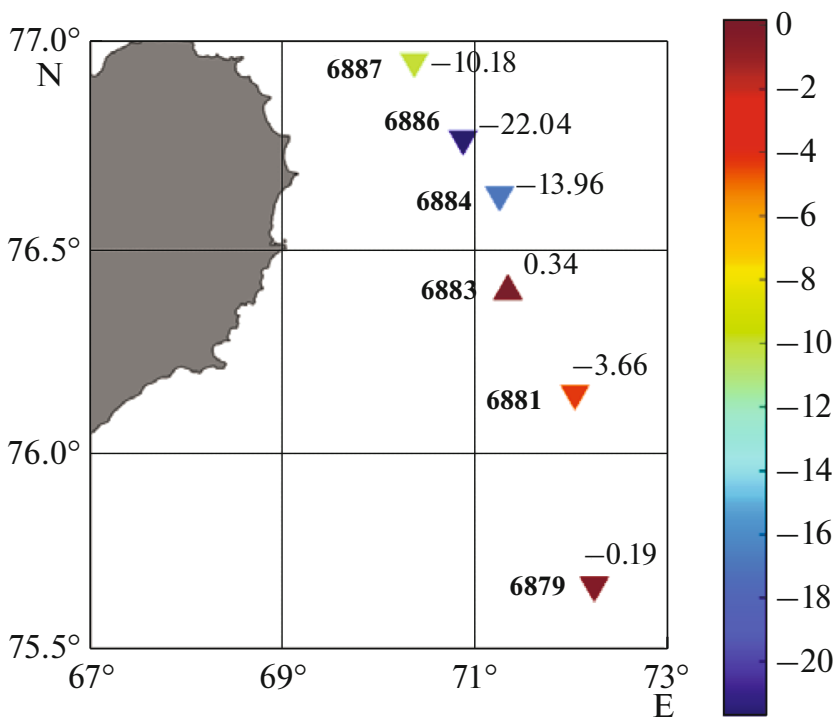

Fig. 5. Calculated $\mathrm{CO}_{2}$ flux ( $\mathrm{mmol} / \mathrm{m}^{2}$ day) at the stations of the section (numbers on the left); the arrows show the flux direction, and numbers on the right, the flux rate; negative values show the gas flux direction from the atmosphere into the water.

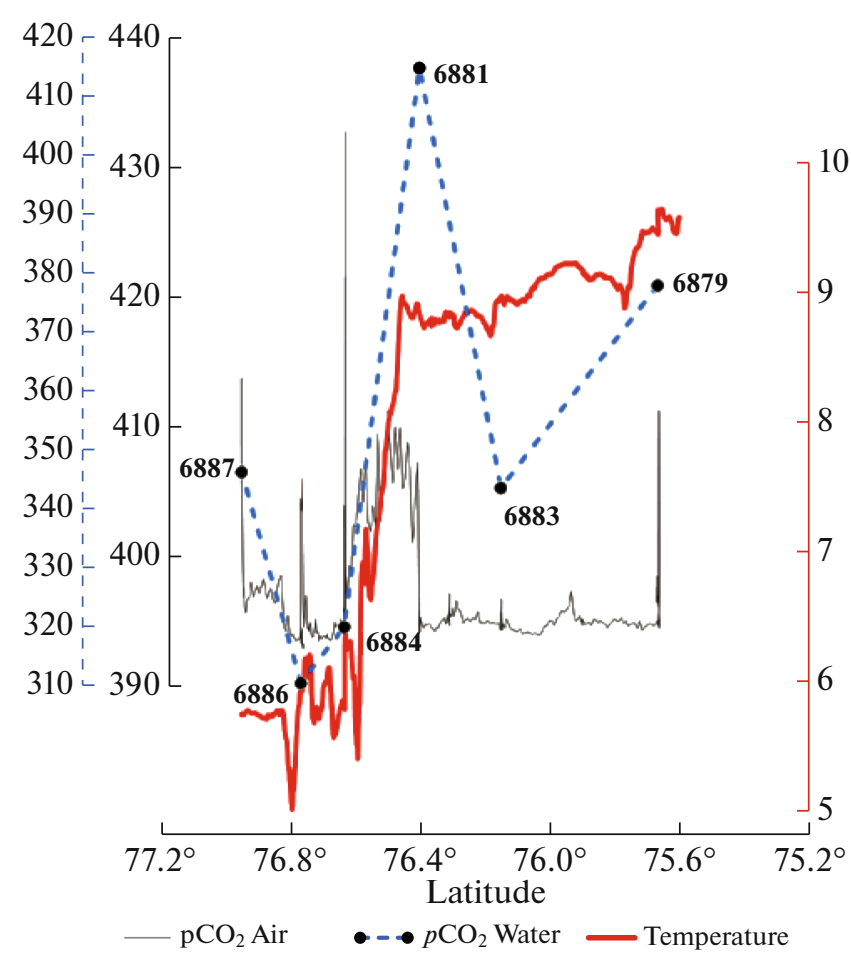

Fig. 6. Variations in the temperature, ${ }^{\circ} \mathrm{C}$, and $\mathrm{CO}_{2}$ partial pressure, $\mathrm{ppm}$, in the surface sea layer and in the surface air layer at the section through the St. Anna Trough.

where $p \mathrm{CO}_{2}$ is much lower than $311-346 \mathrm{ppm}$. In the area of the outer shelf, where the surface layer is freshened by the river runoff (stations 6879 and 6881), $p \mathrm{CO}_{2}$ in water is also lower than in air: 378 and $344 \mathrm{ppm}$ and 394-396 ppm, respectively, which determines the 
$\mathrm{CO}_{2}$ absorption by the sea surface layer. Station 6883 at the southern periphery of the frontal slope stands out by the $p \mathrm{CO}_{2}$ ratio in the surface sea and surface air layers (415 and $394 \mathrm{ppm}$, respectively), which determines the $\mathrm{CO}_{2}$ flux direction from the sea to the atmosphere.

\section{CONCLUSIONS}

The processes, which run in the areas of the outer shelf and continental slope of the Siberian epicontinental seas, play a significant role in the control of the biogeochemical conditions and matter fluxes, as well as in the formation of biological products. These processes are associated with the current climate trends. Indeed, the current trends toward a decrease in the ice cover and an increase in the ice-free period length in the Arctic are most pronounced in the region of the Arctic continental slope.

One of the most important characteristics of matter fluxes in Arctic natural systems is the $\mathrm{CO}_{2}$ exchange at the air-sea boundary. Our study allowed us to ascertain that $\mathrm{CO}_{2}$ comes from the atmosphere into the surface sea layer at a rate of 0.2 to $22 \mathrm{mmol} / \mathrm{m}^{2}$ day in summer over a considerable water area in the region of the outer shelf and continental slope of the Kara Sea. Then, it is redistributed in the water depth due to vertical dynamics and chemical and biological processes.

Our study has shown that the natural systems of individual regions of the Arctic seas can function as active acceptors of $\mathrm{CO}_{2}$ from the atmosphere. An increase in the $\mathrm{CO}_{2}$ flux into seawater shifts the carbonate equilibrium towards an increase in the content of hydrogen ions, that is, decreases $\mathrm{pH}$ of the seawater with corresponding consequences for several components of marine ecosystems, primarily phytoplankton [16]. This is a slow process, which can last for decades depending on a complex of external and internal factors. However, significant climate changes in the Arctic region can accelerate it and aggravate the corresponding response of the Arctic ecosystems. Joint studies of the $\mathrm{CO}_{2}$ content in the near-water atmosphere and the carbonate system of waters make it possible to assess the air-sea $\mathrm{CO}_{2}$ fluxes, the role of Arctic ecosystems in the $\mathrm{CO}_{2}$ absorption from the atmosphere, and the spatial and climatic variability of this process.

\section{FUNDING}

This study was supported by the Ministry of Science and Higher Education of the Russian Federation (State Assignment for Shirshov Institute of Oceanology, Russian Academy of Sciences no. 0128-2021-0007), the Russian Foundation for Basic Research (project no. 20-35-70039), the Russian Science Foundation (project no. 20-17-00200), and the President of the Russian Federation (grant no. MK-860.2020.5).

\section{CONFLICT OF INTEREST}

The authors declare that there is no conflict of interest.

\section{OPEN ACCESS}

This article is licensed under a Creative Commons Attribution 4.0 International License, which permits use, sharing, adaptation, distribution and reproduction in any medium or format, as long as you give appropriate credit to the original author(s) and the source, provide a link to the Creative Commons license, and indicate if changes were made. The images or other third party material in this article are included in the article's Creative Commons license, unless indicated otherwise in a credit line to the material. If material is not included in the article's Creative Commons license and your intended use is not permitted by statutory regulation or exceeds the permitted use, you will need to obtain permission directly from the copyright holder. To view a copy of this license, visit http://creativecommons.org/licenses/by/4.0/.

\section{REFERENCES}

1. O. A. Alekin and Yu. I. Lyakhin, Ocean Chemistry (Gidrometeoizdat, Leningrad, 1984) [in Russian].

2. A. G. Zatsepin, P. O. Zavialov, V. V. Kremenetskiy, et al., "The upper desalinated layer in the Kara Sea," Oceanology (Engl. Transl.) 50, 657-667 (2010).

3. A. G. Zatsepin, S. G. Poyarkov, V. V. Kremenetskiy, et al., "Hydrophysical features of deep water troughs in the western Kara Sea,” Oceanology (Engl. Transl.) 55, 472-484 (2015).

4. P. N. Makkaveev, Z. G. Melnikova, A. A. Polukhin, et al., "Hydrochemical characteristics of the waters in the western part of the Kara Sea," Oceanology (Engl. Transl.) 55, 485-496 (2015).

5. A. A. Polukhin and P. N. Makkaveev, "Features of the continental runoff distribution over the Kara Sea," Oceanology (Engl. Transl.) 57, 19-30 (2017).

6. Guide for Chemical Analysis of Marine and Fresh Waters during Ecological Monitoring of Fishery Reservoirs and Regions of the World Ocean, Prospective for Commercial Fishery, Ed. by V. V. Sapozhnikov (VNIRO, Moscow, 2003) [in Russian].

7. V. M. Sergeeva, I. N. Sukhanova, M. V. Flint, et al., "Phytoplankton of the St. Anna Trough: influence of abiotic factors," Oceanology (Engl. Transl.) 60, 458472 (2020).

8. I. N. Sukhanova, M. V. Flint, E. I. Druzhkova, et al., "Phytoplankton in the northwestern Kara Sea," Oceanology (Engl. Transl.) 55, 547-560 (2015).

9. M. V. Flint, S. G. Poyarkov, A. G. Timonin, and K. A. Soloviev, "The structure of the mesoplankton community in the area of the continental slope of the St. Anna Trough (Kara Sea)," Oceanology (Engl. Transl.) 55, 583-594 (2015).

10. R. G. J. Bellerby, A. Silyakova, G. Nondal, et al., "Marine carbonate system evolution during the EPOCA Arctic pelagic ecosystem experiment in the context of simulated Arctic ocean acidification," Biogeosci. Discuss. 9 (11), 15541-15565 (2012). 
11. A. G. Dickson, J. D. Afghan, and G. C. Anderson, "Reference materials for oceanic $\mathrm{CO} 2$ analysis: a method for the certification of total alkalinity," Mar. Chem. 80 (2-3), 185-197 (2003).

12. S. C. Doney, "The dangers of ocean acidification," Sci. Am. 294 (3), 58-65 (2006).

13. T. W. Drake, S. E. Tank, A. V. Zhulidov, et al., "Increasing alkalinity export from large Russian Arctic rivers,” Environ. Sci. Technol. 52 (15), 8302-8308 (2018). https://doi.org/10.1021/acs.est.8b01051

14. E. R. Lewis and D. W. R. Wallace, Program Developed for $\mathrm{CO}_{2}$ System Calculations (Carbon Dioxide Information Analysis Center, Oak Ridge, TN, 1998), No. CDIAC-105.

15. M. Meredith, M. Sommerkorn, S. Cassotta, et al., "Polar regions," in IPCC Special Report on the Ocean and Cryosphere in a Changing Climate, Ed. by H.-O. Pörtner, (Intergovernmental Panel on Climate Change, Geneva, 2019), Ch. 3.

16. J. C. Orr, V. J. Fabry, O. Aumont, et al., "Anthropogenic ocean acidification over the twenty-first century and its impact on calcifying organisms," Nature 437 (7059), 681-686 (2005).

17. J. C. Orr, "Recent and future changes in ocean carbonate chemistry," Ocean Acidif. 1, 41-66 (2011).

18. A. A. Osadchiev, D. I. Frey, S. A. Shchuka, et al., "Structure of the freshened surface layer in the Kara Sea during ice-free periods," J. Geophys. Res.: Oceans 126 (1), e2020JC016486 (2021).
19. N. V. Pankratova, I. B. Belikov, V. A. Belousov, et al., "Concentration and isotopic composition of methane, associated gases, and black carbon over Russian Arctic seas (shipborne measurements)," Oceanology (Engl. Transl.) 60, 593-602 (2020).

20. A. Polukhin, "The role of river runoff in the Kara Sea surface layer acidification and carbonate system changes," Environ. Res. Lett. 14 (10), (2019). https://doi.org/10.1088/1748-9326/ab421e

21. M. Steinacher, F. Joos, T. L. Frölicher, et al., "Imminent ocean acidification in the Arctic projected with the NCAR global coupled carbon cycle-climate model," Biogeosciences 6 (4), 515-533 (2009).

22. T. Takahashi, S. C. Sutherland, C. Sweeney, et al., "Global sea-air $\mathrm{CO}_{2}$ flux based on climatological surface ocean $p \mathrm{CO}_{2}$, and seasonal biological and temperature effects," Deep Sea Re., Part II 49 (9-10), 16011622 (2002).

23. P. J. Wallhead, R. G. J. Bellerby, A. Silyakova, et al., "Bottom water acidification and warming on the western Eurasian Arctic shelves: dynamical downscaling projections," J. Geophys. Res.: Oceans 122 (10), 81268144 (2017).

24. R. Wanninkhof, "Relationship between wind speed and gas exchange over the ocean revisited," Limnol. Oceanogr. 12 (6), 351-362 (2014). https://doi.org/10.4319/lom.2014.12.351

Translated by $O$. Ponomareva 